Article

\title{
Design and Synthesis of Novel Heterocyclic-Based $4 H$-benzo[ $h]$ chromene Moieties: Targeting Antitumor Caspase 3/7 Activities and Cell Cycle Analysis
}

\author{
Fawzia F. Alblewi ${ }^{1, *}$, Rawda M. Okasha ${ }^{1}$, Areej A. Eskandrani ${ }^{1}$, Tarek H. Afifi ${ }^{1}$, \\ Hany M. Mohamed ${ }^{2,3}{ }^{\oplus}$, Ahmed H. Halawa ${ }^{3}$, Ahmed M. Fouda ${ }^{4}$, Al-Anood M. Al-Dies ${ }^{4,5}{ }^{\oplus}$, \\ Ahmed Mora ${ }^{3}$ and Ahmed M. El-Agrody ${ }^{3}$ (D) \\ 1 Chemistry department, Faculty of Science, Taibah University, Medina 30002, Saudi Arabia; \\ rawdao@yahoo.com (R.M.O.); a.eskandrani@gmail.com (A.A.E.); afifith@yahoo.com (T.H.A.) \\ 2 Chemistry Department, Faculty of Science, Jazan University, Jazan 2097, Saudi Arabia; \\ hanysm83@yahoo.com \\ 3 Chemistry Department, Faculty of Science, Al-Azhar University, Nasr City, Cairo 11884, Egypt; \\ ahmedhalawa_79@yahoo.com (A.H.H.); autobus78@yahoo.com (A.M.); elagrody_am@yahoo.com (A.M.E.-A.) \\ 4 Chemistry Department, Faculty of Scinece, King Khalid University, P.O. Box 9004, Abha 61413, Saudi Arabia; \\ amfouda@hotmail.com (A.M.F.); nood-mansyaa@hotmail.com (A.-A.M.A.-D.) \\ 5 Biology and Chemistry Department, Al-Qunfudah University College, Umm Al-Qura University, \\ Al-Qunfudah 1109, Saudi Arabia \\ * Correspondence: fbalawi@taibahu.edu.sa; Tel.: +966-564221044
}

Received: 15 February 2019; Accepted: 14 March 2019; Published: 18 March 2019

\begin{abstract}
Novel fused chromenes (4,7-11) and pyrimidines (12-16) were designed, synthesized, and evaluated for their mammary gland breast cancer (MCF-7), human colon cancer (HCT-116), and liver cancer (HepG-2) activities. The structural identity of the synthesized compounds was established according to their spectroscopic analysis, such as FT-IR, NMR, and mass spectroscopy. The preliminary results of the bioassay disclosed that some of the target compounds were proven to have a significant antiproliferative effect against the three cell lines, as compared to Doxorubicin, Vinblastine, and Colchicine, used as reference drugs. Particularly, compounds $\mathbf{7}$ and $\mathbf{1 4}$ exerted promising anticancer activity towards all cell lines and were chosen for further studies, such as cell cycle analysis, cell apoptosis, caspase 3/7 activity, DNA fragmentation, cell invasion, and migration. We found that these potent cytotoxic compounds induced cell cycle arrest at the $\mathrm{S}$ and G2/M phases, prompting apoptosis. Furthermore, these compounds significantly inhibit the invasion and migration of the different tested cancer cells. The structure-activity relationship (SAR) survey highlights that the antitumor activity of the desired compounds was affected by the hydrophobic or hydrophilic nature of the substituent at different positions.
\end{abstract}

Keywords: fused chromenes and pyrimidines; cell cycle analysis; cell apoptosis; caspase 3/7 activity; DNA fragmentation; cell invasion; and migration; SAR

\section{Introduction}

Fused chromenes and benzochromenes are notoriously established molecules that exhibit miscellaneous biological activities, such as antibacterial and antifungal activity [1-3], being an anticancer agent [4], blood platelet antiaggregating [5], hypolipidemic [6], antioxidant [7,8], antileishmanial [9], vascular-disrupting [10], anticancer, spectroscopic properties, and fluorescence [11,12] activities and effects. Moreover, the fused chromene nuclei have arisen as an encouraging and desirable scaffold for the development of powerful antitumor agents. For instance, $\beta$-enaminonitrile (A) (LY290181) is an 
effective antiproliferative vehicle for different cell lines, causing a hindrance to the mitosis phase and microtubules [13,14]. The 2- $N$-succinimido derivatives (B) display an anti-rheumatic effect [15], while $\beta$-enaminonitriles (C) [16] have effective cytotoxic and apoptotic behaviors against different cell lines: MCF-7, MDA-MB-231, HepG-2, T-47D, SK-N-MC, KB, and PC3. Furthermore, $\beta$-enaminonitriles/esters (D) [17-22] are reported to be one of the most antiproliferative agents, shown in Figure 1.<smiles>N#CC1=C(N)Oc2c(ccc3ccccc23)C1c1cccc([N+](=O)[O-])c1</smiles>

(A)
(B)<smiles>N#CC1=C(N)Oc2c(ccc3ccccc23)C1c1ccccc1</smiles>

(C)<smiles>[X]C1=C(N)OC(c2ccccc2[R])=C(C=C)C1Br</smiles>

(D)

$$
\begin{gathered}
\mathrm{X}=4-\mathrm{Cl}, 2-\text { or 4- } \mathrm{NO}_{2} \quad \mathrm{R}=4-\mathrm{H}, 4-\mathrm{Cl}, 4-\mathrm{OMe}, 5-\mathrm{NH}_{2} \\
\mathrm{X}=\mathrm{CN}, \mathrm{CO}_{2} \mathrm{Et}
\end{gathered}
$$

Figure 1. Structures of fused chromene derivatives (blue-highlighted) with biological effects.

Moreover, $\beta$-enaminonitriles (E) $(\mathrm{R}=3-\mathrm{OMe}, 4-\mathrm{OH})$ demonstrated high potency for acetylcholinesterase (hAChE) inhibitors in the low micromolar range. The $\beta$-enaminonitriles compound $(\mathrm{F})(\mathrm{R}=2,4-\mathrm{OMe}, 4-\mathrm{NO} 2,3,4,5-\mathrm{OMe}, 3,4-\mathrm{Cl})$ [23] has strong blood-brain barrier permeability profiles, determined in the parallel artificial membrane permeability assay (PAMPA), and experience low toxicity in the HepG-2 cells. The $\beta$-enaminonitrile compounds (G) exhibit antiproliferative and $c$-Src kinase inhibitory activities [24], and the $\beta$-enaminonitriles (H) [25] demonstrate cell cycle arrest at the $\mathrm{S}$ and G2/M phases, inducing apoptosis and $c$-Src kinase inhibitory, presented in Figure 2.<smiles>[R]c1ccc(C2c3c(nc4c(c3N)CCCC4)Oc3ccc4ccccc4c32)cc1</smiles>

$\mathrm{R}=3-\mathrm{OMe}, 4-\mathrm{OH}$ hAChE Inhibitors<smiles>[R]c1ccc(C2c3c(nc4c(c3N)CCCC4)Oc3ccc4ccccc4c32)cc1</smiles>

$\mathrm{R}=$ 2,4-OMe, 4- $\mathrm{NO}_{2}, 3,4,5-\mathrm{OMe}, 3,4-\mathrm{Cl}$ Blood brain barrier and low toxicity<smiles>[R]c1ccc(C2C(C#N)=C(N)Oc3ccc4ccccc4c32)cc1</smiles>

$\mathrm{R}=3-\mathrm{Cl}, 3-\mathrm{NO}_{2}, 3-\mathrm{OH}$, 4-OMe, 2,3-Cl

Src kinase inhibitory and anti-proliferative activities<smiles>[R]c1ccc(C2C(C#N)=C(N)Oc3ccc4cc([R])ccc4c32)cc1</smiles>

$\mathrm{R}=\mathrm{Br}$, OMe $\mathrm{R}_{1}=4-\mathrm{Cl}, 4-\mathrm{OMe}$

Cell cycle arrest and Src kinase inhibitory

Figure 2. Structures of fused chromenes (red-highlighted) with cytotoxic and apoptotic effects.

Additionally, fused pyrimidines displayed anticancer characteristics. For instance, the amino-imino compounds (I) [20-22,26], methylimino compounds (J) [20,22], and the amino-imino compounds (K) [20-22] have higher significant potent antitumor activities against MCF-7, HCT-116, and HepG-2, in comparison to the different standard drugs: Doxorubicin, Vinblastine, and Colchicine, shown in Figure 3. 
<smiles>COc1cc2c(c3ccccc13)Oc1ncn(N)c(=N)c1C2[Al]</smiles>

$\mathrm{Ar}=4-\mathrm{FC}_{6} \mathrm{H}_{5}, 4-\mathrm{ClC}_{6} \mathrm{H}_{5}$, 4- $\mathrm{BrC}_{6} \mathrm{H}_{5}, 4-\mathrm{MeOC}_{6} \mathrm{H}_{5}$

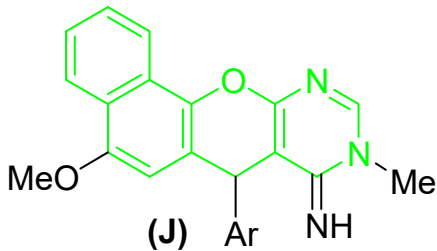

$\mathrm{Ar}=4-\mathrm{BrC}_{6} \mathrm{H}_{5}, 4-\mathrm{MeOC}_{6} \mathrm{H}_{5}$<smiles>COc1cc2c(c3ccccc13)Oc1ncnc(N)c1C2[Al]</smiles>

$\mathrm{Ar}=4-\mathrm{FC}_{6} \mathrm{H}_{5}, 4-\mathrm{ClC}_{6} \mathrm{H}_{5}, 4-\mathrm{BrC}_{6} \mathrm{H}_{5}$

Figure 3. Structure of some fused pyrimidine derivatives (green-highlighted) with cytotoxic and apoptotic effects.

These findings encouraged us to develop a novel series of chromene and pyrimidine molecules with the aim of discovering their antitumor features [17-22,26]. The SAR of the desired molecules stressed the influence of the substituents at different positions on the antitumor activity. In addition, the most potent compounds $\mathbf{7}$ and $\mathbf{1 4}$ were selected to investigate the mechanism of their actions, using various examinations, such as cell cycle analyses, Annexin V assay, caspase 3/7 activity, and DNA fragmentation. Our results revealed that the prepared compounds trigger cancer cell arrest in the $S$ and G2/M phases, and induce caspase dependent apoptosis. The prepared compounds were also able to inhibit cancer cells' invasion and migration.

\section{Results and Discussion}

\subsection{Chemistry}

$\beta$-enaminonitrile is a versatile precursor to the manufacturing of several functionalized heterocycles with a remarkable biological performance [13-22]. Thus, the synthesis of chromene- and pyrimidine-containing compounds has drawn considerable notice, seen in Schemes 1-4. The synthetic methodology was initiated by reacting the 4-methoxy-1-naphthol (1), 2,4-dimethoxybenzaldehyde (2), and $\mathrm{CH}_{2}(\mathrm{CN})_{2}$ (3), or ethyl cyanoacetate (5), in an ethanolic piperidine solution. The reaction was employed for microwave irradiation for $2 \mathrm{~min}$ at $140{ }^{\circ} \mathrm{C}$ to produce the $\beta$-enaminonitrile (4), however, the formation of the $\beta$-enaminoester (6) was unsuccessful. This result could be attributed to the steric hindrance of the methoxy group at the 2-position of the 2,4-dimethoxybenzaldehyde. Compound 4 displayed optical activity of zero rotation (i.e., it was optically inactive) and, thus, was in the form of a racemic $( \pm)$ mixture $[17,26]$, as shown in Scheme 1 .
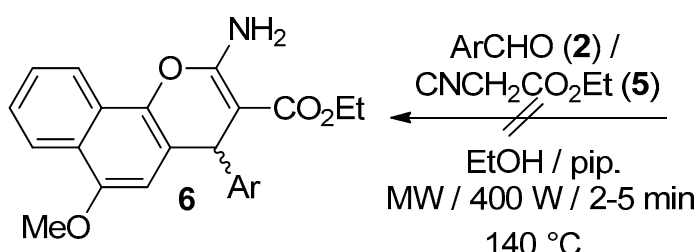<smiles>COc1ccc(O)c2ccccc12</smiles>

$\mathrm{Ar}=2,4-\mathrm{diMeOC}_{6} \mathrm{H}_{3}$

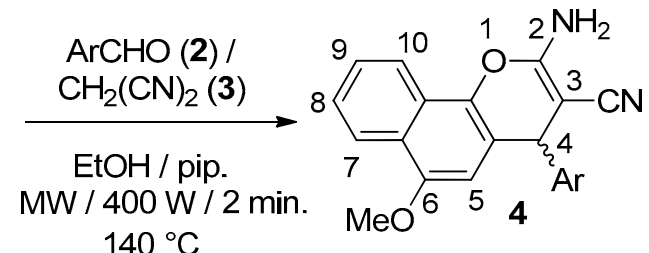

$140{ }^{\circ} \mathrm{C}$

Scheme 1. Synthesis of $4 H$-benzo[ $h]$ chromene derivative 4 .

The synthesis of the fused chromene derivatives (7-10) was achieved via the reaction of the $\beta$-enaminonitrile 4 with different nuclophilic reagents, namely: acetic anhydride, benzaldehyde, triethyl orthoformate, and dimethylformamide-dineopentylacetal (DMF-DPA), while the treatment of 9 with the $\mathrm{NH}_{3}$ gas bubbled in methanol at ambient temperature for $1 \mathrm{~h}$, giving the open chain product, 2-aminomethyleneamino derivative 11, presented in Scheme 2. 


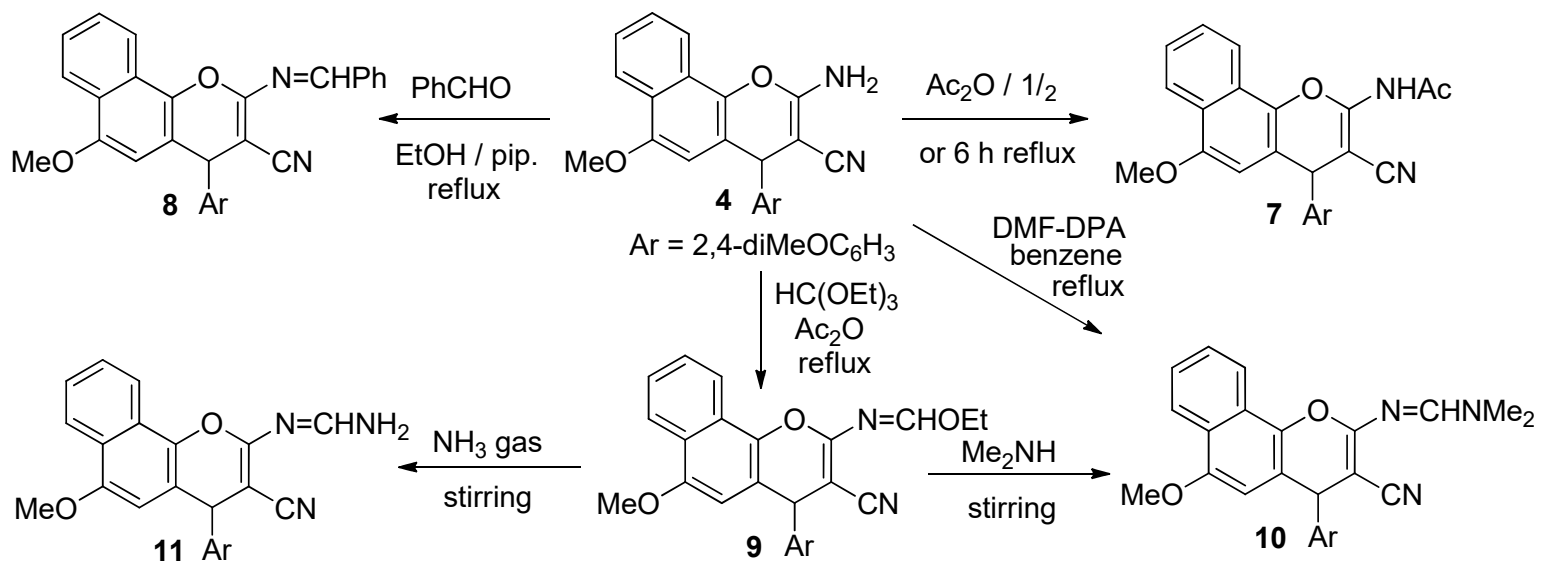

Scheme 2. Synthesis of 2-substituted chromenes 7-11.

The compounds 4 and $\mathbf{9}$ are beneficial precursors for the construction of an assortment of novel heterocycle-based chromenopyrimidine moieties. Therefore, the condensation of compound 4 with formic acid under reflux yielded pyrimidine-8-one derivative (12), while the reaction of 4 with formamide under reflux failed; thus, 8-aminopyrimidine (13) was not formed. Alternatively, compound $\mathbf{1 3}$ can be attained by the cyclization of $\mathbf{1 1}$ in a refluxed ethanolic piperidine solution [27], shown in Scheme 3.

(11)

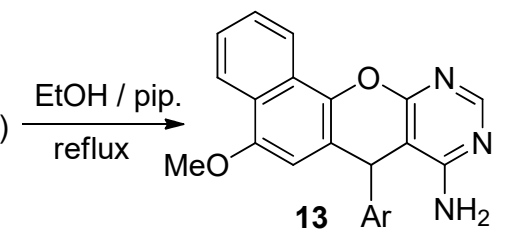<smiles>COc1cc2c(c3ccccc13)OC(N)=C(C(C)C)C2[Mg]C(C)C(N)=O</smiles>

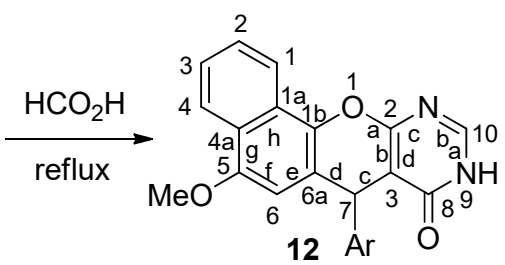

$\mathrm{Ar}=2,4-\mathrm{diMeOC}_{6} \mathrm{H}_{3}$

Scheme 3. Synthesis of the chromenopyrimidine derivatives, 12 and $\mathbf{1 3 .}$

The interface of the imidate 9 with methanamine or hydrazine hydrate allowed the cycloaddition of the methylimino 14 and the amino-imino 15 products. Furthermore, compound 15 reacted with benzaldehyde in a refluxed ethanolic piperidine and generated a Schiff base open product, 9-benzylideneaminopyrimidine 16, as seen in Scheme 4.

Moreover, the methine protons of compounds 4, 7-11, and 12-16 are chiral centers. The identity of all the new compounds were verified, according to their spectral data, IR, ${ }^{1} \mathrm{H} N \mathrm{NMR},{ }^{13} \mathrm{C} \mathrm{NMR}$, and MS data (see Experimental section and Supplementary Materials).

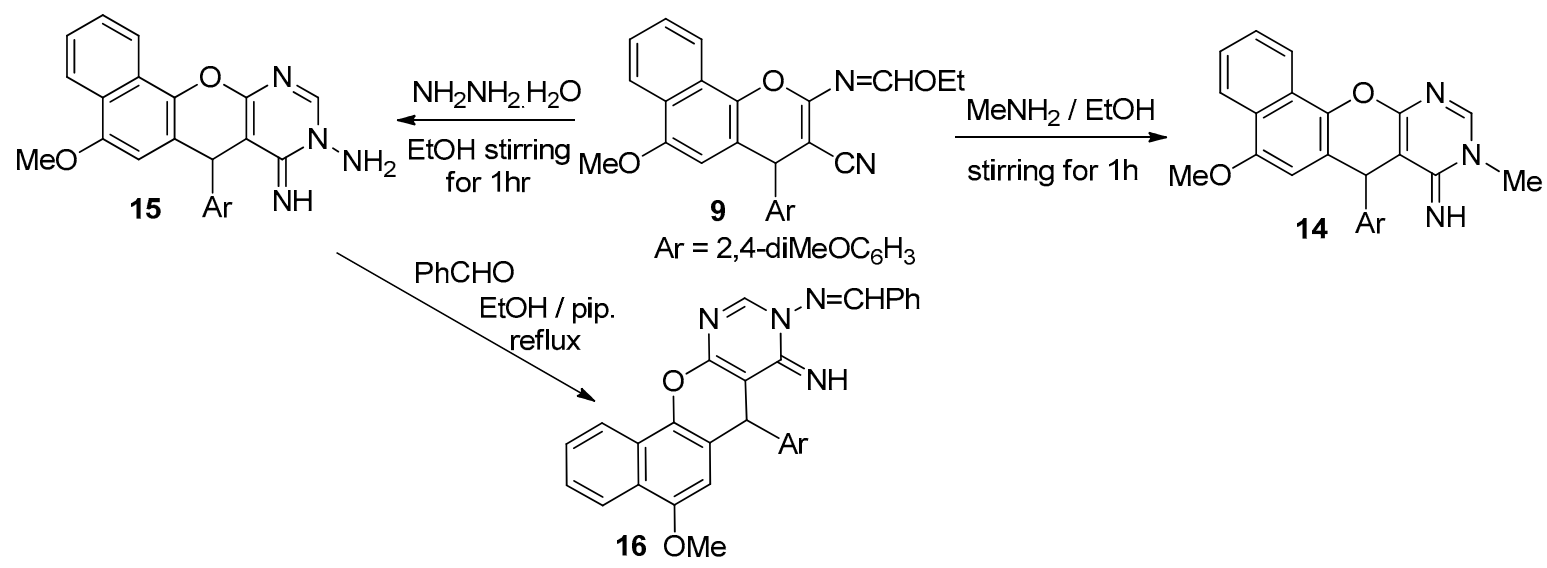

Scheme 4. Synthesis of compounds 14-16. 


\subsection{Biological Evaluation}

\subsubsection{In Vitro Cytotoxic Activity}

The in vitro antiproliferative performance of compounds 4, 7-11, and 12-16 towards breast cancer MCF-7, human colon cancer HCT-116, and liver cancer HepG-2 cell lines was explored, as shown in Figure 4 and Table 1 . The judicious choice of the cell lines and standard drugs was instigated by the asserted anticancer behavior of a number of benzochromene and chromenopyrimidine molecules [13-26]. Their cytotoxic activities were evaluated via the 2-(4,5-dimethylthiazol-2-yl)-3,5-diphenyl-2H-tetrazol-3-ium bromide (MTT) colorimetric assay [28,29], and the obtained $\mathrm{IC}_{50}$ values were in comparison to the values of the reference cytotoxic drugs: Doxorubicin, Vinblastine, and Colchicine.

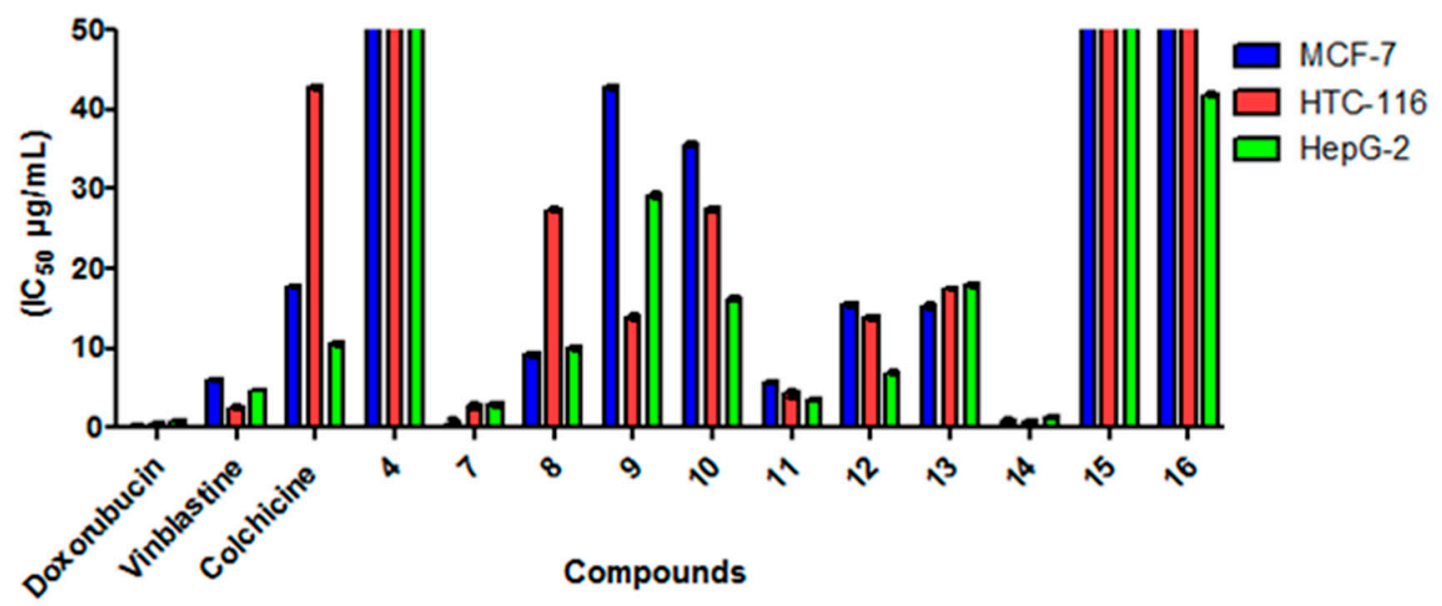

Figure 4. IC $_{50}$ values for MCF-7, HCT-116, and HepG-2 tumor cells after $24 \mathrm{~h}$ treatment with fused chromenes 4, 7-11 and pyrimidines 12-16.

From the attained results in Table 1, compounds 7, 14, and 11 were discovered to be the most potent derivatives of all the tested compounds against the MCF-7 cancer cell line, as it was 8.7, 6.8, and 1.1 times, and 25.3, 19.7, and 3.1 times more active than both the standard drugs Vinblastine and Colchicine, respectively, while compounds 8, 13, and 12 exhibited strong activity against the MCF-7 cancer cell, in comparison to Colchicine. Additionally, compound $\mathbf{1 4}$ was the most active candidate against HCT-116, as it was 3.3 and 53.5 times more active than both standard drugs, Vinblastine and Colchicine, respectively, and compound 7 was equipotent to Vinblastine. In the meantime, compounds $\mathbf{7}, \mathbf{1 1}, \mathbf{1 2}, \mathbf{9}, \mathbf{1 3}, \mathbf{8}$, and $\mathbf{1 0}$ displayed strong activity against the HCT-116 cancer cell, due to them being 15.3, 10.0, 3.1, 3.1, 2.5, 1.6, and 1.6 times more active than Colchicine. On the other hand, the cytotoxicity evaluation in the HepG-2 cell line divulged that compounds 14, 7, and 11 were the most active congener against HepG-2 with 3.3, 1.5, and 1.2 times, and 7.6, 3.5, and 2.7 times more activity, in comparison to Vinblastine and Colchicine, respectively. Additionally, compounds 12 and 8 exhibited strong activity against the HepG-2 cancer cell with them being 1.5 and 1.1 times more active than Colchicine. Compound $\mathbf{1 4}$ was almost equipotent to Doxorubicin against the MCF-7, HCT-116, and HepG-2 cancer cell lines. 
Table 1. Cytotoxic activities of target compounds against MCF-7, HCT-116, and HepG-2 tumor cells.<smiles>[R]C1=C(C#N)C(Br)c2cc(OC)c3ccccc3c2O1</smiles>

4,7-11 Ar<smiles>COc1cc2c(c3ccccc13)Oc1nc[nH]c(=O)c1C2[Al]</smiles><smiles>COc1cc2c(c3ccccc13)Oc1ncnc(N)c1C2[Al]</smiles><smiles>[R]n1cnc2c(c1=N)C(Br)c1cc(OC)c3ccccc3c1O2</smiles>

$\mathrm{Ar}=2,4-\mathrm{diMeOC}_{6} \mathrm{H}_{3}$

\begin{tabular}{|c|c|c|c|c|}
\hline \multirow{2}{*}{ Compound } & \multirow{2}{*}{$\mathbf{R}$} & \multicolumn{3}{|c|}{$\mathrm{IC}_{50}(\mu \mathrm{g} / \mathrm{mL})^{\mathrm{a}}$} \\
\hline & & MCF-7 & НСТ-116 & HepG-2 \\
\hline 4 & $\mathrm{NH}_{2}$ & $\mathrm{w}$ & $\mathrm{w}$ & $\mathrm{w}$ \\
\hline 7 & NHAC & $0.7 \pm 0.23$ & $2.8 \pm 0.23$ & $3.0 \pm 0.11$ \\
\hline 8 & $\mathrm{~N}=\mathrm{CHPh}$ & $9.3 \pm 0.14$ & $27.4 \pm 0.13$ & $10.1 \pm 0.15$ \\
\hline 9 & $\mathrm{~N}=\mathrm{CHOEt}$ & $42.9 \pm 0.11$ & $14.0 \pm 0.3$ & $29.2 \pm 0.3$ \\
\hline 10 & $\mathrm{~N}=\mathrm{CHNMe}_{2}$ & $35.6 \pm 0.14$ & $27.5 \pm 0.11$ & $16.2 \pm 0.1$ \\
\hline 11 & $\mathrm{~N}=\mathrm{CHNH}_{2}$ & $5.8 \pm 0.02$ & $4.3 \pm 0.32$ & $3.7 \pm 0.03$ \\
\hline 12 & - & $15.6 \pm 0.13$ & $13.9 \pm 0.17$ & $7.0 \pm 0.14$ \\
\hline 13 & - & $15.3 \pm 0.21$ & $17.5 \pm 0.04$ & $18.0 \pm 0.05$ \\
\hline 14 & $\mathrm{Me}$ & $0.9 \pm 0.21$ & $0.8 \pm 0.12$ & $1.4 \pm 0.1$ \\
\hline 15 & $\mathrm{NH}_{2}$ & w & w & w \\
\hline 16 & $\mathrm{~N}=\mathrm{CHPh}$ & $\mathrm{w}$ & $\mathrm{w}$ & 41.9 \\
\hline Vinblastine & - & $6.1 \pm 0.03$ & $2.6 \pm 0.08$ & $4.6 \pm 0.01$ \\
\hline Colchicine & - & $17.7 \pm 0.01$ & $42.8 \pm 0.02$ & $10.6 \pm 0.04$ \\
\hline Doxorubicin & - & $0.4 \pm 0.01$ & $0.5 \pm 0.02$ & $0.9 \pm 0.04$ \\
\hline
\end{tabular}

${ }^{\mathrm{a}} \mathrm{IC}_{50}$ values expressed in $\mu \mathrm{g} / \mathrm{mL}$ as the mean values of triplicate wells from at least three experiments are reported as the mean \pm standard error. $\mathrm{w}=$ weak activity $\left(\mathrm{IC}_{50} \geq 75 \mathrm{~g} / \mathrm{mL}\right)$.

\subsubsection{Cell Cycle Analysis}

Numerous anticancer molecules employ their impact via blocking cell cycle progression, inducing apoptosis, or the merged effect of both. [30,31]. To verify the causal relation of cell proliferation inhibition and cell cycle arrest, the cell cycle distribution was probed, using the Propidium Iodide Flow Cytometry Kit assay. The cell cycle phase distribution, which was examined, showing the collected propidium iodide fluorescence intensity on the FL2, is displayed in Figure 5a. Compound 7 experienced an increased cell number at the G2/M phases after $24 \mathrm{~h}$, accompanied by a decreased cell number at the $S$ and G1 phases in the MCF-7 and HepG-2 cells. However, in the case of the HCT-116 cells, compound 7 demonstrated cancer cell arrest at both the $S$ and G2/M phases. Furthermore, compound 14 exhibited a significant increased cell number at the $S$ and G2/M phases, with a decreased cell number at the G1 phase (Figure 5b). The G2 checkpoint inhibits cells from entering mitosis, and this is commonly observed in cells that have been exposed to DNA-damaging agents and the topoisomerase blockers [32]. 


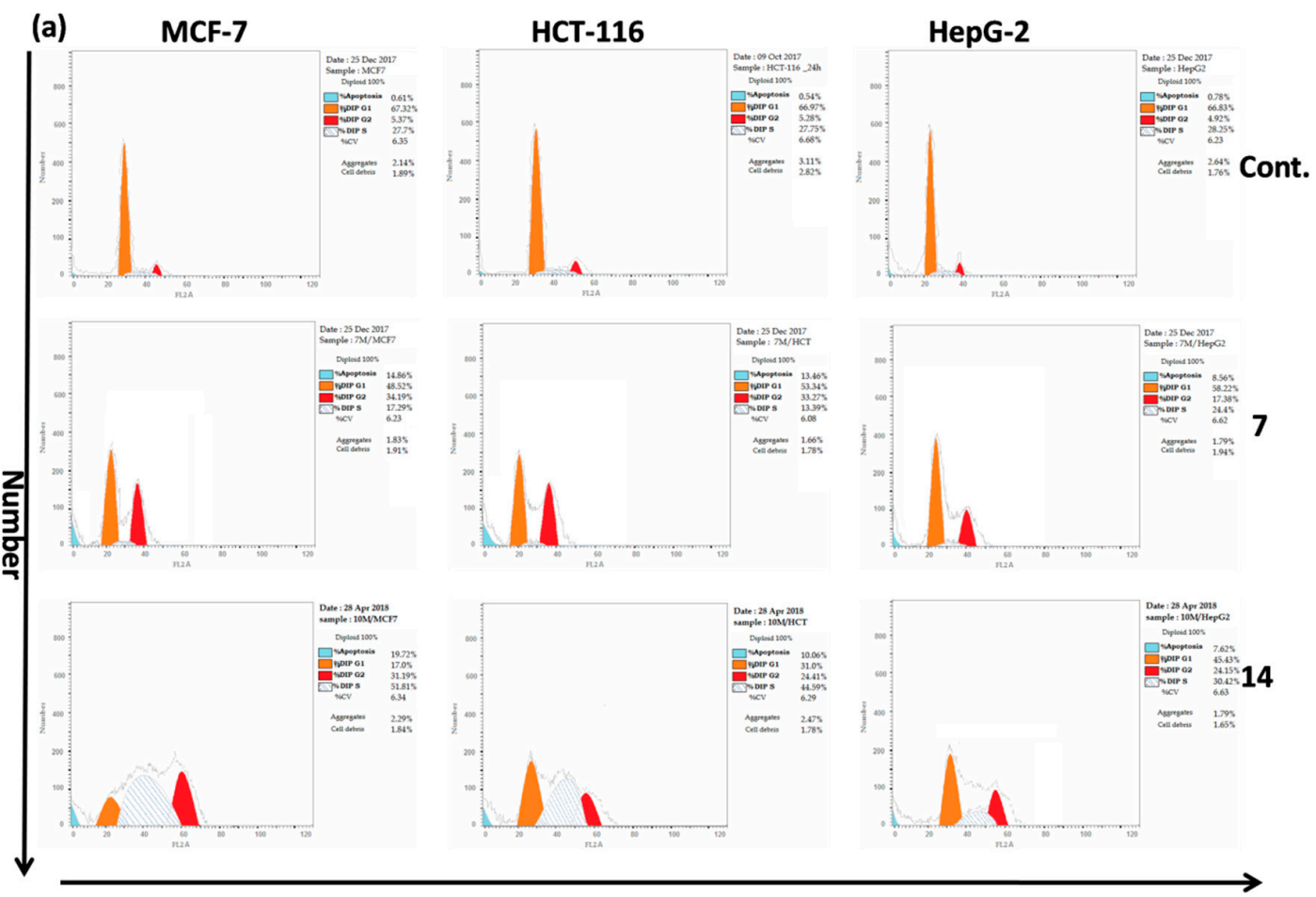

(b)
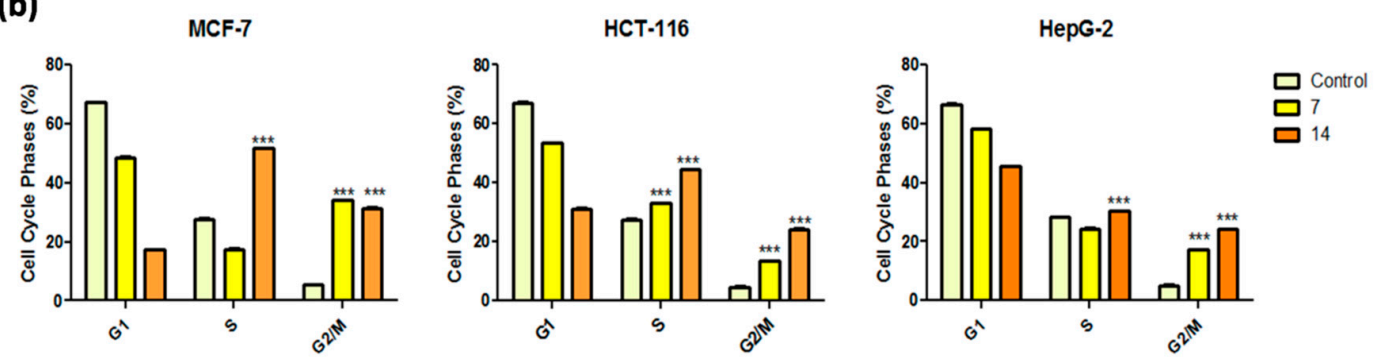

Figure 5. (a) Cell cycle profile of MCF-7, HCT-116, and HepG-2 cancer cells were analyzed with PI. The plot shows the distribution of cells in G1 (orange) and G2/M (red) phases of the cell cycle, and cells in the $S$ phase are located between the two peaks, represented by the hatched curve. (b) Bar charts, representing the percentage of cell populations in MCF-7, HCT-116, and HepG-2 cells, were treated with compounds 7 and $14(4 \mu \mathrm{g} / \mathrm{mL})$ for $24 \mathrm{~h}$. The data are expressed as the mean \pm SD of three independent experiments in triplicate. Significances are shown in comparison to control cells (*** $p<0.001)$.

\subsubsection{Cell Apoptosis}

Further investigation on the mechanism, dealing with apoptotic cell death and induced by compounds $\mathbf{7}$ and $\mathbf{1 4}$ on the different treated cells, was explored. This study was performed using the Annexin V assay, which is beneficial for the detection of translocated phosphatidylserine (PS), a hallmark of apoptosis [33]. The dot plot flow cytometry data of the stained cells with the Annexin V-FITC and PI is shown in Figure 6a. After $24 \mathrm{~h}$ of exposure, the MCF-7, HCT-116, and HepG-2 cells had undergone early and late apoptosis when treated with compound $\mathbf{7}$ or $\mathbf{1 4}$, in comparison to the untreated control cells. A considerable increase in the number of apoptotic cells was also observed in all cells after exposure to compound $\mathbf{7}$ or $\mathbf{1 4}$ (Figure 6b). Necrosis was not observed in any of the treatment conditions, suggesting cell death occurred primarily through the induction of apoptosis. 


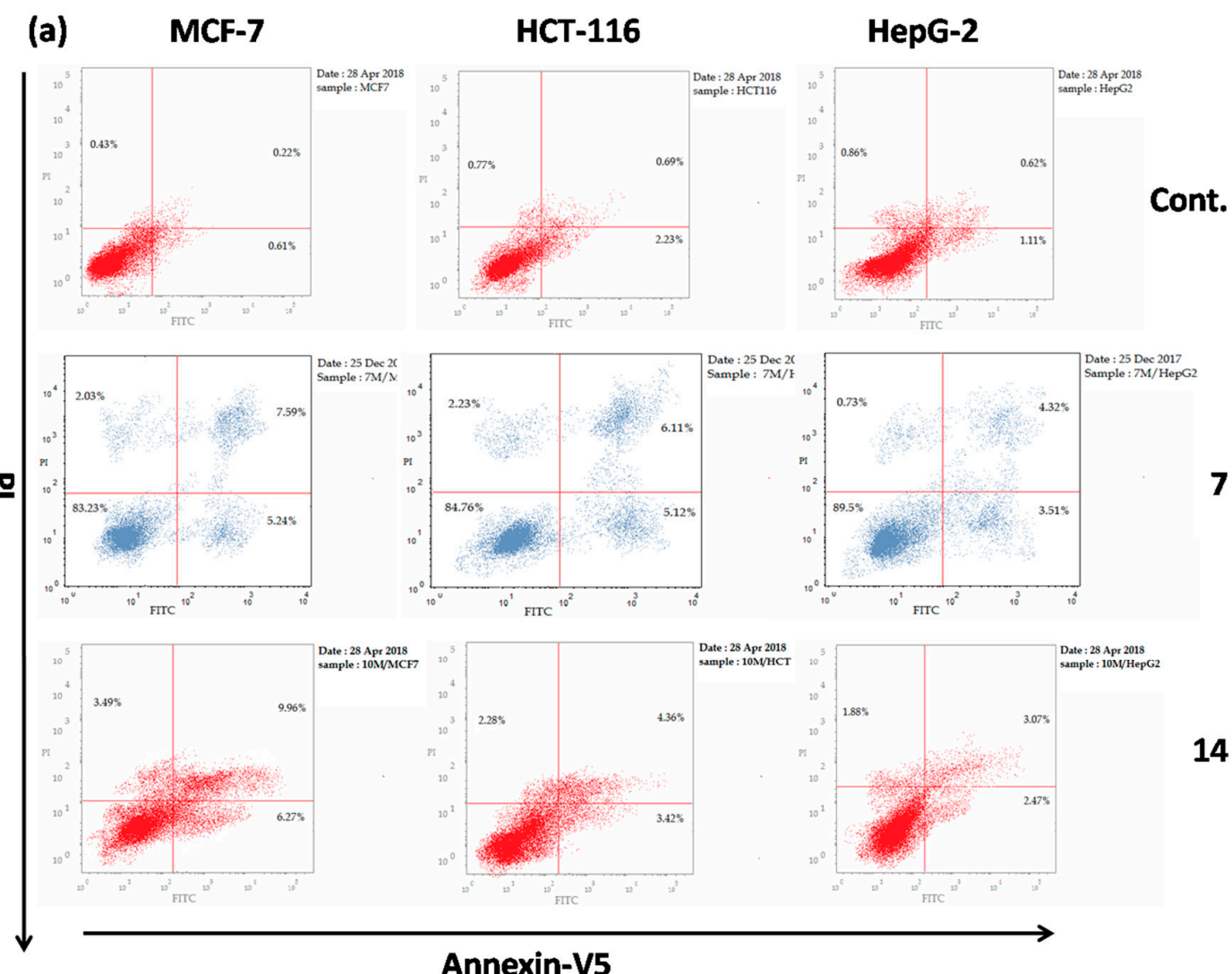

7

(b)

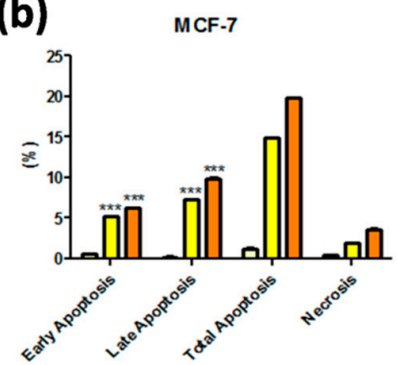

HCT-116

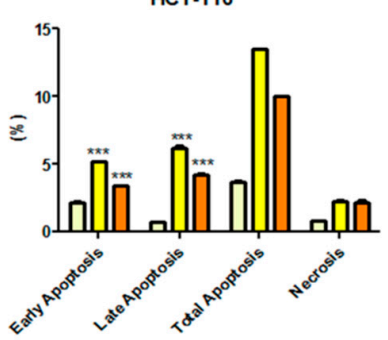

HepG-2

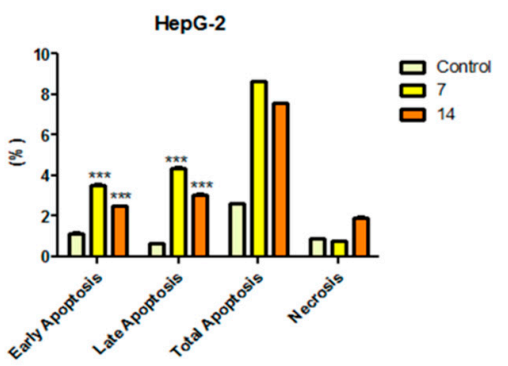

Figure 6. (a) Dot plot of Annexin V/PI stained cells treated with the indicated drugs for $24 \mathrm{~h}$. (b) Apoptosis percentage of MCF-7, HCT-116, and HepG-2 cells after incubation with compounds 7 and $14(4 \mu \mathrm{g} / \mathrm{mL})$ for $24 \mathrm{~h}$. The data are expressed as the mean $\pm \mathrm{SD}$ of three independent experiments in triplicate. Significances are shown in comparison to control cells $(* * *<0.001)$.

\subsubsection{Caspase $3 / 7$ Activity}

Apoptosis is a type of programmed cell death that is managed by the members of the caspase family of cysteine proteases. Procaspases are activated in response to the diverse cell death stimuli, ultimately producing an amplifying, irreversible proteolytic cascade [34]. To further establish the apoptotic procedure generated by the tested compounds, the effector caspases' activity was assessed, using the Cell Event ${ }^{\mathrm{TM}}$ Caspase-3/7 Green Detection kit (Figure 7a). All treated cells have a higher percentage of apoptotic cells than the basal level of apoptosis seen in the control cells. The levels of caspase- $3 / 7$ of all the tested cells, treated with compounds 7, were more or less equivalent to the reference drug Doxorubicin. Moreover, compound 14 significantly amplified the level of caspase-3/7 in all the tested cells, which were double the levels achieved by Doxorubicin (Figure $7 \mathrm{~b}$ ). Taken together, these data revealed that compound 7 and 14 triggered cell apoptosis by activating the effector caspases 3 and 7 . 


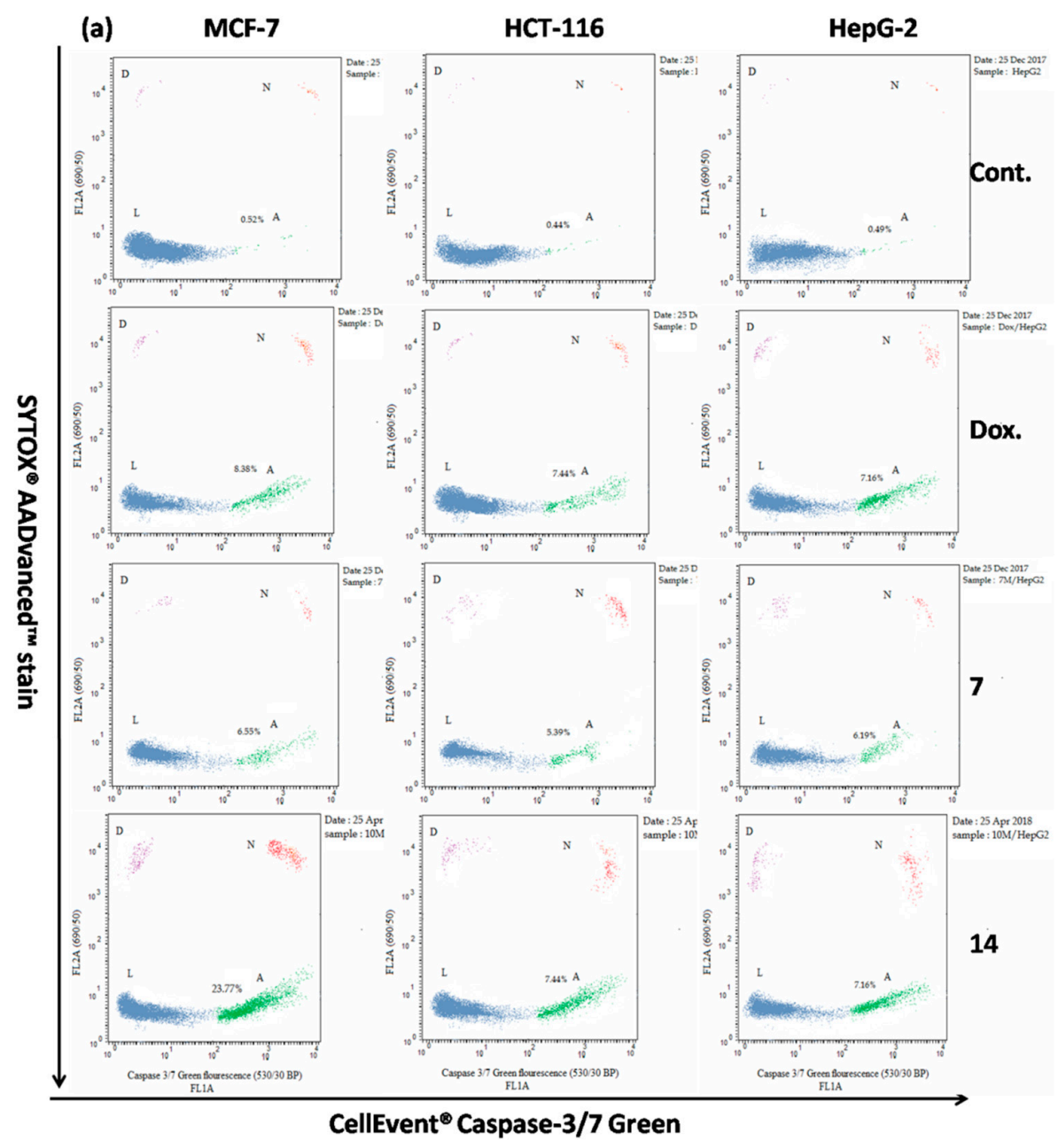

(b)

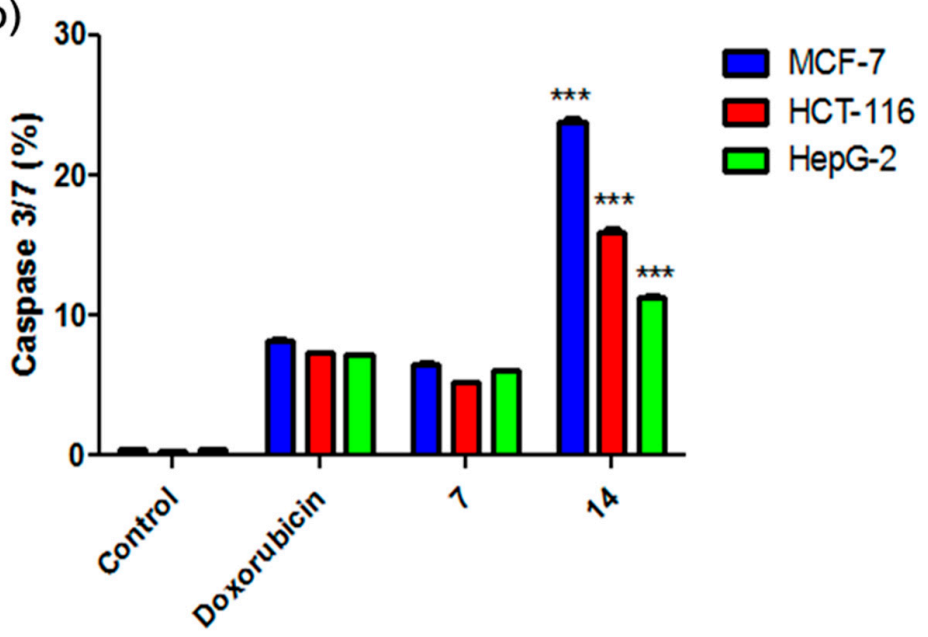

Figure 7. (a) Detected caspase activity in cancer cells was treated with the indicated drugs for $24 \mathrm{~h}$, using the CellEvent ${ }^{\circledR}$ Caspase-3/7 Green Flow Cytometry kit. Fluorescence emission was collected, using a $530 / 30$ bandpass filter for the CellEvent ${ }^{\circledR}$ reagent and a $690 / 50$ bandpass filter for the SYTOX ${ }^{\circledR}$ AADvanced $^{\mathrm{TM}}$ stain (also provided in the kit). L, viable cells; A, apoptotic cells; N, necrotic cells;. and D, dead cells. (b) Caspase-3/7 activity percentage of MCF-7, HCT-116, and HepG-2 cells after incubation with compounds 7 and $14(4 \mu \mathrm{g} / \mathrm{mL})$ for $24 \mathrm{~h}$. The data are expressed as the mean $\pm \mathrm{SD}$ of three independent experiments in triplicate. Significances are shown in comparison to doxorubicin-treated cells $(* * *<0.001)$. 


\subsubsection{DNA Fragmentation}

Caspases play principal roles in the induction of DNA fragmentation, which is the most common characteristic biochemical event in apoptosis pathways [35]. The DNA fragmentation was quantitatively determined, using the diphenylamine (DPA) reagent. The results were attained from the relative quantity of DNA fragments, integrated with the caspases' activity results acquired from before. We found that compound 7 showed more or less the same DNA fragmentation percentage as Doxorubicin in all the tested cells. These results also demonstrated the significant influence of compound 14 on DNA fragmentation, which was almost double the results obtained by Doxorubicin in all the tested cells (Figure 8). Overall, compounds $\mathbf{7}$ and $\mathbf{1 4}$ encourage apoptosis through DNA fragmentation and executioner caspase- $3 / 7$ activation.

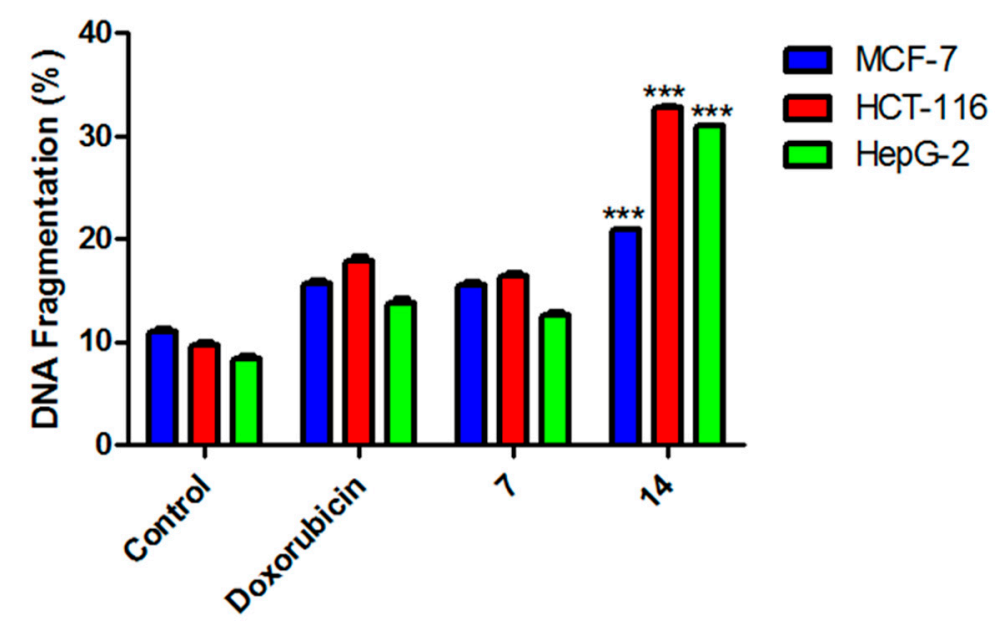

Figure 8. DNA fragmentation percentage of MCF-7, HCT-116, and HepG-2 cells after incubation with compounds 7 and $14(4 \mu \mathrm{g} / \mathrm{mL})$ for $24 \mathrm{~h}$. The data are expressed as the mean $\pm \mathrm{SD}$ of three independent experiments in triplicate. Significances are shown in comparison to doxorubicin treated cells $(* * *<0.001)$.

\subsubsection{Cell Invasion and Migration}

In this study, the cell cycle arrest at the G2/M phases raised the possibility that the tested compounds might manipulate cell invasion and migration. Compounds $\mathbf{7}$ and $\mathbf{1 4}$ exhibited a substantial decrease in the cell invasion and cell migration percentage in all the tested cells, compared to the untreated control cells (Figure 9). Microtubules play an imperative role in cell migration and invasion through numerous pathways [36]. The possible effect of the tested compounds on the microtubules might be the reasons for the demonstrated data.

All the results reveal that the potent antitumor effect of compound 7 is due to the inhibition of the $\mathrm{G} 2 / \mathrm{M}$ cell cycle checkpoint. This action is associated with the induction of the executioner caspase $3 / 7$ that induces DNA fragmentation, ending with apoptosis, as shown with the externalization of phosphatidylserine (PS), which is a hallmark of apoptosis. The data has also highlighted the possible effect of compound 7 on DNA damage, topoisomerase enzyme inhibition, and the disruption of the microtubules assembly, which may be the first sight of action [37,38]. Finally, compound 7 may be useful as a novel potent anticancer drug in the future. 
(a)

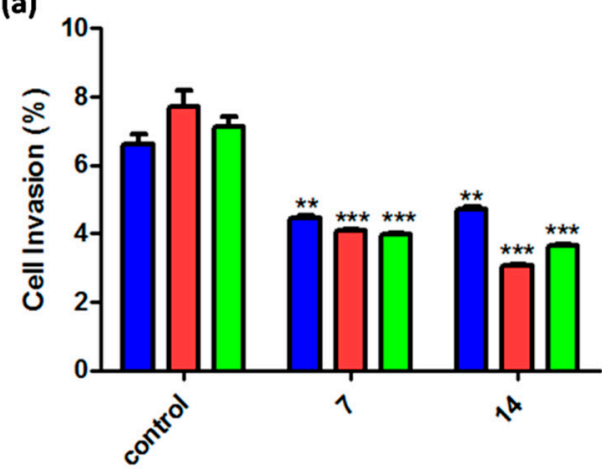

(c)

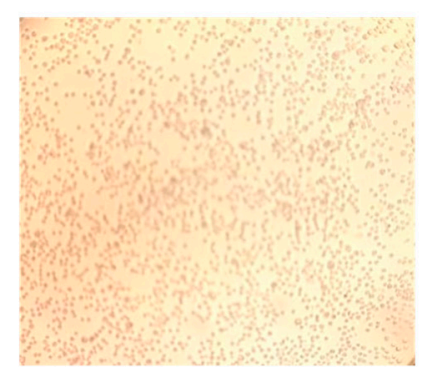

(b)

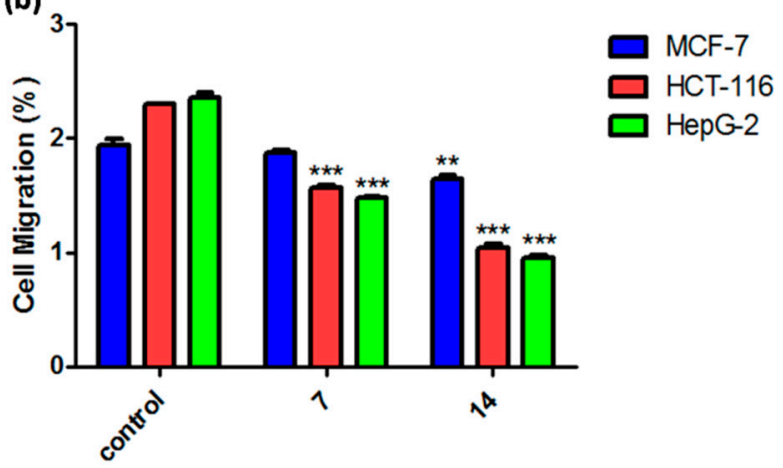

7

14

Figure 9. Cell (a) invasion and (b) migration percentage of MCF-7, HCT-116, and HepG-2 cells after incubation with compounds $\mathbf{7}$ and $\mathbf{1 4}(4 \mu \mathrm{g} / \mathrm{mL})$ for $24 \mathrm{~h}$. The data are expressed as the mean \pm SD of three independent experiments in triplicate. Significances are shown in comparison to control cells $\left({ }^{* *} p<0.01 ;{ }^{* *} p<0.001\right)$. (c) Matrigel invasion assay in MCF7 control cells, co-cultured cells with compounds 7 and 14. Cells that crossed the Matrigel-coated filter were fixed, stained, and counted. Six random microscopic fields were counted for each group.

\subsubsection{SAR Studies}

The preliminary SAR study fixated on the impact of replacement at the 2-position or the fused rings at the 2-, 3-positions on the antitumor activities of the synthesized compounds. In an assessment of the cytotoxic activities of the two sets of fused chromenes (4, 7-11) and pyrimidines (12-16) against the MCF-7 cell line, we found that the highest growth inhibitory effect of the first series 4, 7-11 was associated with the presence of the hydrophobic groups, $-\mathrm{NHAc}$ and $-\mathrm{N}=\mathrm{CHNH}_{2}$, at the 2-positon of the $4 \mathrm{H}$-benzo[h]chromene moiety for compounds 7 and $\mathbf{1 1}$ with $\mathrm{IC}_{50}$ values of 0.7 and $5.8 \mu \mathrm{g} / \mathrm{mL}$, which is considered excellent activity, relative to Vinblastine and Colchicine $\left(\mathrm{IC}_{50}=6.1\right.$ and $\left.17.7 \mu \mathrm{g} / \mathrm{mL}\right)$, respectively. Meanwhile, concerning the inhibitory effect of the second series 12-16, the highest growth inhibitory effect was associated with the existence of a fused pyrimidine ring with hydrophobic groups (=NH-8, -Me-9) at the 2-, 3-positions of the chromene moiety for compound $\mathbf{1 4}$ with an $\mathrm{IC}_{50}$ value of $0.9 \mu \mathrm{g} / \mathrm{mL}$, in comparison to Vinblastine $\left(\mathrm{IC}_{50}=6.1 \mu \mathrm{g} / \mathrm{mL}\right)$ and Colchicine $\left(\mathrm{IC}_{50}=17.7\right.$ $\mu \mathrm{g} / \mathrm{mL}$ ), respectively. Thus, the strong lipophilic characteristic of the molecule performs a crucial role in generating the antitumor effect. From this perspective, the existence of the hydrophobic substituent in the pyrimidine moiety would be much more crucial for such activity than in the $4 \mathrm{H}$-benzo[h]chromene moiety.

Furthermore, compound 7 and $\mathbf{1 1}\left(\mathrm{IC}_{50}=2.8\right.$ and $\left.4.3 \mu \mathrm{g} / \mathrm{mL}\right)$, bearing hydrophobic substituents -NHAc and $-\mathrm{N}=\mathrm{CHNH}_{2}$ at the 2-position for the first series, exhibited an increase in activity against the HCT-116 cancer cell, compared to Vinblastine, Colchicine, and other derivatives. The introduction of a pyrimidine ring at the 2-, 3-positions of compound 4 with hydrophobic groups $\left(=\mathrm{NH}-8,-\mathrm{NH}_{2}-9\right)$ for compound $\mathbf{1 4}\left(\mathrm{IC}_{50}=0.8 \mu \mathrm{g} / \mathrm{mL}\right)$ resulted in a remarkable enhancement of the potency against the 
HCT-116 cancer cell, in evaluation against Vinblastine and Colchicine $\left(\mathrm{IC}_{50}=2.6\right.$ and $\left.42.8 \mu \mathrm{g} / \mathrm{mL}\right)$. On the other hand, compounds 7, 8, 9, and 10, and 12 and 13, for the first and second series, respectively, exhibited efficient cytotoxicity in comparison to Colchicine, suggesting that the pyrimidine nucleus at the 2-, 3-positions with the hydrophobic group at the 8-, 9-positions was imperative for the activities towards the HCT-116 cancer cell, rather than the chromene nucleus with the hydrophobic group at the 2-position.

Concerning the activity against HepG-2, compounds $\mathbf{7}$ and $\mathbf{1 1}$ for the first series and compound 14 for the second series were the most active analogs through this study with $\mathrm{IC}_{50}$ values of 3.0, 3.7, and $1.4 \mu \mathrm{g} / \mathrm{mL}$, respectively, in comparison to the reference drugs, Vinblastine and Colchicine $\left(\mathrm{IC}_{50}\right.$ $=4.6$ and $10.6 \mu \mathrm{g} / \mathrm{mL})$. These results imply that the introduction of the hydrophobic groups $(=\mathrm{NH}-8$, -Me-9) in the pyrimidine moiety was indispensable for the activity against HepG-2, compared to the hydrophobic groups -NHAc and $-\mathrm{N}=\mathrm{CHNH}_{2}$ at the 2-positon of the chromene moiety.

In addition, compound $\mathbf{1 4}$ had the strongest impact against MCF-7, HCT-116, and HepG-2 as evaluated against Doxorubicin. Finally, we can deduce that the substitution pattern at the 2-position or fused rings at the 2,3-positions on the synthesized chromene and pyrimidine moieties is a crucial element for antitumor activity. The incorporation of the pyrimidine rings at the 2-, 3-positions with the hydrophobic groups as $(=\mathrm{NH}-8,-\mathrm{Me}-9)$ or $\left(-\mathrm{N}=\mathrm{CHNH}_{2}\right)$ at the 2-position of the chromene nucleus is favorable and greatly enriches the activity, more so than the other hydrophobic and hydrophilic groups.

\section{Materials and Methods}

\subsection{General Information}

Commercial-grade solvents and reagents were purchased from Sigma-Aldrich (St. Louis, MO, USA) and used without further purification. Melting points were measured with a Stuart Scientific (UK) apparatus and are uncorrected. IR spectra were determined as KBr pellets on a Jasco FT/IR 460 plus spectrophotometer (Jasco, Japan). The optical activities of the synthesized compounds were measured using a CARL ZEISS JENA 267628 polarimeter. ${ }^{1} \mathrm{H}-\mathrm{NMR},{ }^{13} \mathrm{C}-\mathrm{NMR},{ }^{13} \mathrm{C}-\mathrm{NMR} / \mathrm{APT}$, and ${ }^{13} \mathrm{C}-\mathrm{NMR} / \mathrm{DEPT}$ spectra were recorded using a Bruker $\mathrm{AV} 500 \mathrm{MHz}$ spectrometer (Bruker, Billerica, MA, USA). Chemical shifts $(\delta)$ are expressed in parts per million (ppm). The microwave synthesis was performed using a mono-mode Milestone Sr1 device (Milestone, Shelton, CT, USA), while the MS spectra were measured using a Shimadzu GC/MS-QP5050A spectrometer (Shimadzu, Japan). Elemental analyses were carried out at the Regional Centre for Mycology \& Biotechnology (RCMP), Al-Azhar University, Cairo, Egypt and the results were within $\pm 0.25 \%$. Analytical thin layer chromatography (TLC) on silica gel precoated $\mathrm{F}_{254}$ (Merck, Billerica, MA, USA) plates was used to check the purity of the compounds.

\subsection{Synthesis}

\section{2-Amino-4-(2,4-dimethoxyphenyl)-6-methoxy-4H-benzo[h]chromene-3-carbonitrile (4)}

Chromene compound 4 was prepared according to the previously reported procedure [39].

2-Acetylamino-4-(2,4-dimethoxyphenyl)-6-methoxy-4H-benzo[h]chromene-3-carbonitrile (7). $\beta$-enaminonitrile 4 $(3.88 \mathrm{~g}, 0.01 \mathrm{~mol})$ was refluxed in acetic anhydride $(20 \mathrm{~mL})$ for $0.5 \mathrm{or} 6 \mathrm{~h}$. Upon the removal of the solvent, the resulting solid was collected, washed with cooled methanol, filtered, dried, and recrystallized from ethanol to provide 7 as a colorless solid, yield: 97\%, m.p. $167-168{ }^{\circ} \mathrm{C} ; \mathrm{C}_{25} \mathrm{H}_{22} \mathrm{~N}_{2} \mathrm{O}_{5}$ (430.45); calcd; \% C: 69.76, \% H: 5.15, \% N: 6.51; found; \% C: 69.81, \% H: 5.18, \% N: 6.57.

2-Benzylideneamino-4-(2,4-dimethoxyphenyl)-6-methoxy-4H-benzo[h]chromene-3-carbonitrile (8). A 2 h. refluxed reaction of $\beta$-enaminonitrile $4(3.88 \mathrm{~g}, 0.01 \mathrm{~mol})$, benzaldehyde $(1.06 \mathrm{~g}, 0.01 \mathrm{~mol})$ and piperidine $(0.5 \mathrm{~mL})$ in $20 \mathrm{~mL}$ ethanol produced compound 8, which was recrystallized from ethanol/benzene as a yellow solid, yield: 63\%, m.p. $215-216{ }^{\circ} \mathrm{C} ; \mathrm{C}_{30} \mathrm{H}_{24} \mathrm{~N}_{2} \mathrm{O}_{4}(476.52)$; calcd; \% C: 75.61, \% H: 5.08, \% N: 5.88; found; \% C: 75.55 , \% H: 4.99, \% N: 5.79 . 
2-Ethoxymethyleneamino-4-(2,4-dimethoxyphenyl)-6-methoxy-4H-benzo[h]chromene-3-carbonitrile A combination of $\beta$-enaminonitrile $4(3.88 \mathrm{~g}, 0.01 \mathrm{~mol})$ and triethyl orthoformate $(1.48 \mathrm{~g}, 0.01 \mathrm{~mol})$ in a boiled $\mathrm{Ac}_{2} \mathrm{O}(30 \mathrm{~mL})$ for $2 \mathrm{~h}$, followed by a recrystallization from benzene to afford compound 9 as a yellow solid, yield: 91\%, m.p. $186-187{ }^{\circ} \mathrm{C} ; \mathrm{C}_{26} \mathrm{H}_{24} \mathrm{~N}_{2} \mathrm{O}_{5}$ (444.48); calcd; \% C: 70.26, \% H: 5.44, \% N: 6.30; found; \% C: 70.30 , \% H: 5.48, \% N: 6.41 .

2-Dimethylaminomethyleneamino-4-(2,4-dimethoxyphenyl)-6-methoxy-4H-benzo[h]chromene-3-carbonitrile (10) Method (a): $\beta$-enaminonitrile 4 (3.88 g, $0.01 \mathrm{~mol})$ with dimethylformaide-dineopentylacetal (DMF-DPA) $(2.31 \mathrm{~g}, 0.01 \mathrm{~mol})$ and benzene $(30 \mathrm{~mL})$ was refluxed for $3 \mathrm{~h}$. The isolated solid was recrystallized from benzene to give 10 as a colorless solid, yield: 90\%, m.p. 206-207 ${ }^{\circ} \mathrm{C}_{;} \mathrm{C}_{26} \mathrm{H}_{25} \mathrm{~N}_{3} \mathrm{O}_{4}$ (443.49); calcd; \% C: 70.41, \% H: 5.68, \% N: 9.47; found; \% C: 70.48, \% H: 5.71, \% N: 9.50. Method (b): The imidate $9(4.44 \mathrm{~g}, 0.01 \mathrm{~mol})$ and dimethylamine $(0.45 \mathrm{~g} .0 .01 \mathrm{~mol})$ in methanol $(30 \mathrm{~mL})$ was stirred at room temperature for $1 \mathrm{~h}$ then left overnight to provide $\mathbf{1 0}$ (m.p., mixed m.p., identical IR and MS spectrum).

2-Aminomethyleneamino-4-(2,4-dimethoxyphenyl)-6-methoxy-4H-benzo[h]chromene-3-carbonitrile Compound 11 was prepared from the imidate $9(4.44 \mathrm{~g}, 0.01 \mathrm{~mol})$ and $\mathrm{NH}_{3}$ gas bubbled in methanol (30 $\mathrm{mL})$, according to the procedure described for compound 10 (Method b). Compound 11 was recrystallized from ethanol as a colorless solid, yield: 85\%, m.p. 230-231 ${ }^{\circ} \mathrm{C} ; \mathrm{C}_{24} \mathrm{H}_{21} \mathrm{~N}_{3} \mathrm{O}_{4}(415.44)$; calcd; \% C: 69.39, \% H: 5.10, \% N: 10.11; found; \% C: $69.29, \%$ H: 5.00, \% N: 10.00 .

7-(2,4-Dimethoxyphenyl)-5-methoxy-7H,9H-benzo[h]chromeno[2,3-d]pyrimidin-8-one (12). A 3-5 h refluxing of $\beta$-enaminonitrile $4(3.88 \mathrm{~g}, 0.01 \mathrm{~mol})$ and formic acid $(4.6 \mathrm{~g}, 1 \mathrm{~mol})$, followed by the removal of excess formic acid, resulted in the formation of $\mathbf{1 2}$, which was recrystallized from ethanol/benzene as a colorless solid, yield: 83\%, m.p. $209-210{ }^{\circ} \mathrm{C} ; \mathrm{C}_{24} \mathrm{H}_{20} \mathrm{~N}_{2} \mathrm{O}_{5}$ (416.43); calcd; \% C: 69.22, \% H: 4.84, \% N: 4.84; found; \% C: 69.33 , \% H: $4.92, \%$ N: 6.82.

8-Amino-7-(2,4-dimethoxyphenyl)-5-methoxy-7H-benzo[h]chromeno[2,3-d]pyrimidine

Boiling compound $11(4.15 \mathrm{~g}, 0.01 \mathrm{~mol})$ in a pipridine/ethanol solution for $2 \mathrm{~h}$ provided compound 13, which was recrystallized from ethanol as a colorless solid, yield: 74\%, m.p. $220-221{ }^{\circ} \mathrm{C} ; \mathrm{C}_{24} \mathrm{H}_{21} \mathrm{~N}_{3} \mathrm{O}_{4}$ (415.44); calcd; \% C: 69.39, \% H: 5.10, \% N: 10.11; found; \% C: 69.30, \% H: 5.00, \% N: 10.02.

7-(2,4-Dimethoxyphenyl)-5-methoxy-8-imino-9-methyl-7H-benzo[h]chromeno[2,3-d]pyrimidine Compound 14 was synthesized via the reaction of the imidate 9 ( $4.44 \mathrm{~g}, 0.01 \mathrm{~mol})$ and methanamine $(0.31 \mathrm{~g}, 0.01 \mathrm{~mol})$ in methanol $(30 \mathrm{~mL})$, pursuing a similar approach to the one for compound 11. Compound 14 was recrystallized from ethanol/benzene as a colorless solid, yield: 65\%, m.p. $223-224$ ${ }^{\circ} \mathrm{C}$; its MS $(\mathrm{m} / \mathrm{z}), 429\left(\mathrm{M}^{+}, 50.8\right)$ with a base peak at $292(100) ; \mathrm{C}_{25} \mathrm{H}_{23} \mathrm{~N}_{3} \mathrm{O}_{4}$ (429.47); calcd; \% C: 69.92, \% H: 5.40, \% N: 9.78; found; \% C: 70.00, \% H: 5.50, \% N: 9.82.

9-Amino-7-(2,4-dimethoxyphenyl)-5-methoxy-8-imino-7H-benzo[h]chromeno[2,3-d]pyrimidine

The replacing of methanamine in the aforementioned procedure with hydrazine hydrate $(0.5 \mathrm{~g}$, $0.01 \mathrm{~mol}$ ) supplied compound 15, which was recrystallized from benzene as a colorless solid, yield: 73\%, m.p. 198-199 ${ }^{\circ} \mathrm{C} ; \mathrm{C}_{24} \mathrm{H}_{22} \mathrm{~N}_{4} \mathrm{O}_{4}$ (430.46); calcd; \% C: 66.97, \% H: 5.15, \% N: 13.02; found; \% C: $70.00, \%$ H: $5.24, \%$ N: 12.94 .

9-Benzylideneamino-7-(2,4-dimethoxyphenyl)-5-methoxy-8-imino-7H-benzo[h]chromeno[2,3-d]pyrimidine (16). A $2 \mathrm{~h}$. refluxed combination of $15(4.30 \mathrm{~g}, 0.01 \mathrm{~mol})$ and benzaldehyde $(1.06 \mathrm{~g}, 0.01 \mathrm{~mol})$ in ethanol $(30 \mathrm{~mL})$ and piperidine $(0.5 \mathrm{~mL})$ produced the open chain product 16 after a recrystallization from ethanol/benzene as a yellow solid, yield: 94\%, m.p. $220-221{ }^{\circ} \mathrm{C} ; \mathrm{C}_{31} \mathrm{H}_{26} \mathrm{~N}_{4} \mathrm{O}_{4}(518.56)$; calcd; \% C: 71.80, \% H: 5.05, \% N: 10.80; found; \% C: 71.77, \% H: 5.01, \% N: 10.76. 


\subsection{Biological Screening}

\subsubsection{Cell Culture}

The tumor cell lines, breast adenocarcinoma (MCF-7), human colon carcinoma (HCT-116), and hepatocellular carcinoma (HepG-2), were obtained from the American Type Culture Collection (ATCC, Rockville, MD). The cells were grown on an RPMI-1640 medium, supplemented with 10\% inactivated fetal calf serum and $50 \mu \mathrm{g} / \mathrm{mL}$ gentamycin. The cells were maintained at $37{ }^{\circ} \mathrm{C}$ in a humidified atmosphere with $5 \% \mathrm{CO}_{2}$ and were subcultured two to three times a week.

\subsubsection{Cytotoxicity Evaluation using Viability Assay}

The cytotoxic activity was appraised, using the 2-(4,5-dimethylthiazol-2-yl)-3,5-diphenyl-2Htetrazol-3-ium bromide (MTT) colorimetric assay, as reported previously [28,29].

\subsubsection{Cell-Cycle Analysis}

The effect of compounds $\mathbf{7}$ and $\mathbf{1 4}$ on the DNA content by cell cycle progression were evaluated, utilizing MCF-7, HCT, and HepG-2 cells, as reported previously [40].

\subsubsection{Apoptosis Analysis by Flow Cytometry}

The apoptosis assay of compounds $\mathbf{7}$ and $\mathbf{1 4}$ was performed with an Annexin V-FITC/PI double-staining apoptosis detection kit (K101, Biovison), as reported previously [33].

\subsubsection{Caspase 3/7 Activity Assay}

The caspase activity was measured after cell incubation for $24 \mathrm{~h}$ with compounds $\mathbf{7}$ and $\mathbf{1 4}$ $(4 \mu \mathrm{g} / \mathrm{mL})$, using a CellEvent ${ }^{\mathrm{TM}}$ Caspase-3/7 Green Flow Cytometry Assay Kit (C10427, Invitrogen), as reported previously [34].

\subsubsection{DNA Fragmentation}

The DNA fragmentation of compounds 7 and $\mathbf{1 4}$ was quantitatively determined, utilizing the diphenylamine (DPA) reagent, according to the method of Boraschi and Maurizi (1998) [41]. The optical density was determined at $600 \mathrm{~nm}$ in the $\mathrm{S}$ (supernatant before cell lysis), $\mathrm{T}$ (pellet with the intact DNA), and B (supernatant with fragmented DNA) fractions, respectively. The percentage of the DNA fragmentation was calculated as follows:

$$
\% \text { Fragmented DNA }=S+T / S+T+B \times 100
$$

\subsubsection{Cell Invasion Assay}

Deregulated cell migration with the set compounds was performed, exploiting the Transwell chamber with a non-coated membrane (96-well HTS Transwell Permeable Supports with $8 \mu \mathrm{m}$ pores, Cat. No. 3374, Corning, Life Sciences), as reported previously [36].

\subsubsection{Statistics}

The statistical analysis was performed by the GraphPad Prism 5.01 (GraphPad software, Inc., San Diego, CA, USA). The experiments were analyzed, using one- or two-way ANOVA, followed by a Tukey post hoc test. The statistical significance indicated that ${ }^{*} p \leq 0.05,{ }^{* *} p \leq 0.01$, and ${ }^{* * *} p \leq 0.001$.

\section{Conclusions}

Several fused chromenes (7-11) and pyrimidines (12-16) were synthesized, via the exploitation of $\beta$-Enaminonitrile 4 as a precursor. The pharmacological analysis was undertaken to assess the effect of the substituents and the pyrimidine rings on the antitumor activities. Most of the synthesized 
compounds exhibited effective antitumor activities against the three tumor cell lines: (MCF-7), (HCT-116), and (HepG-2). Furthermore, the presence of the pyrimidine rings at the 2, 3-positions with the hydrophobic group as $(=\mathrm{NH}-8,-\mathrm{Me}-9)$ or $\left(-\mathrm{N}=\mathrm{CHNH}_{2}\right)$ at the 2-position of the chromene nucleus significantly enhances activity, in comparison to the other hydrophobic and/or hydrophilic groups. In summary, compounds $\mathbf{7}$ and $\mathbf{1 4}$ exhibit potent cytotoxic and antiproliferative effects on the three cancer cells through the caspase-dependent apoptosis mechanism. DNA damage, the inhibition of the Topoisomerase enzyme, or the disruption of the microtubules' assembly may be the reason for the induced S \& G2/M-phases' arrest in this study, which will require further studies in the future.

Supplementary Materials: The following are available online. Spectral data of 2-substituted $4 H$-benzo $[h]$ chromene derivatives $(4-11,13,14)$; Spectral data of $7 H$-benzo[ $h]$ chromeno[2,3- $d]$ pyrimidine derivatives (12-16).

Author Contributions: A.M.E.-A., F.F.A., T.H.A., H.M.M., A.M.F., A.H.H and R.M.O. conceived and designed the experiments; A.-A.M.A.-D. performed the experiments; A.M. and A.A.E. implemented the biological study. All authors analyzed the data, wrote the paper, edited English language and discussed the results and commented on the manuscript.

Funding: This research received no external funding.

Acknowledgments: The author deeply thanks the Regional Center for Mycology \& Biotechnology (RCMP), Al-Azhar University, Cairo, Egypt, for carrying out the antitumor study and elemental analyses and also, the authors would like to express gratitude to Malak T. Mahmoud for editing and revising the manuscript.

Conflicts of Interest: The authors declare no conflict of interest.

\section{References}

1. Singh, G.; Sharma, A.; Kaur, H.; Ishar, M. Chromanyl-isoxazolidines as Antibacterial agents: Synthesis, biological evaluation, quantitative structure activity relationship, and molecular docking studies. Chem. Biol. Drug. Des. 2016, 87, 213-223. [CrossRef]

2. Bingi, C.; Emmadi, N.R.; Chennapuram, M.; Poornachandra, Y.; Kumar, C.G.; Nanubolu, J.B.; Atmakur, K. One-pot catalyst free synthesis of novel kojic acid tagged 2-aryl/alkyl substituted-4H-chromenes and evaluation of their antimicrobial and anti-biofilm activities. Bioorg. Med. Chem. Lett. 2015, 25, 1915-1919. [CrossRef] [PubMed]

3. Killander, D.; Sterner, O. Synthesis of the bioactive benzochromenes pulchrol and pulchral, metabolites of Bourreria pulchra. Eur. J. Org. Chem. 2014, 8, 1594-1596. [CrossRef]

4. Reddy, B.V.S.; Divya, B.; Swaina, M.; Rao, T.P.; Yadav, J.S.; Vishnu Vardhan, M.V. A domino Knoevenagel hetero-Diels-Alder reaction for the synthesis of polycyclic chromene derivatives and evaluation of their cytotoxicity. Bioorg. Med. Chem. Lett. 2012, 22, 1995-1999. [CrossRef] [PubMed]

5. Lee, K.-S.; Khil, L.-Y.; Chae, S.-H.; Kim, D.; Lee, B.-H.; Hwang, G.-S.; Moon, C.-H.; Chang, T.-S.; Moon, C.-K. Effects of DK-002, a synthesized (6aS,cis)-9,10-Dimethoxy-7,11b-dihydroindeno[2,1-c]chromene-3,6a-diol, on platelet activity. Life Sci. 2006, 78, 1091-1097. [CrossRef] [PubMed]

6. Sashidhara, K.V.; Kumar, M.; Modukuri, R.K.; Srivastava, A.; Puri, A. Discovery and synthesis of novel substituted benzochromins as orally active lipid modulating agents. Bioorg. Med. Chem. Lett. 2011, 21, 6709-6713. [CrossRef] [PubMed]

7. Fadda, A.A.; Berghot, M.A.; Amer, F.A.; Badawy, D.S.; Bayoumy, N.M. Synthesis and antioxidant and antitumor activity of novel pyridine, chromene, thiophene and thiazole derivatives. Arch. Pharm. Chem. Life Sci. 2012, 345, 378-385. [CrossRef] [PubMed]

8. Csepanyi, E.; Szabados-Furjesi, P.; Kiss-Szikszai, A.; Frensemeier, L.M.; Karst, U.; Lekli, I.; Haines, D.D.; Tosaki, A.; Istvan Bak, I. Antioxidant properties and oxidative transformation of different chromone derivatives. Molecules 2017, 22, 588. [CrossRef] [PubMed]

9. Foroumadi, A.; Emami, S.; Sorkhi, M.; Nakhjiri, M.; Nazarian, Z.; Heydar, S.; Ardestani, S.; Poorrajab, F.; Shafiee, A. Chromene-based synthetic chalcones as potent antileishmani-al agents: Synthesis and biological activity. Chem. Biol. Drug. Des. 2010, 75, 590-596. [CrossRef] 
10. Kasibhatla, S.; Gourdeau, H.; Meerovitch, K.; Drewe, J.; Reddy, S.; Qiu, L.; Zhang, H.; Bergeron, F.; Bouffard, D.; Yang, Q.; et al. Discovery and mechanism of action of a novel series of apoptosis inducers with potential vascular targeting activity. Mol. Cancer Ther. 2004, 3, 1365-1373.

11. Matwijczuk, A.; Kluczyk, D.; Górecki, A.; Niewiadomy, A.; Gagoś, M. Spectroscopic Studies of Fluorescence Effects in Bioactive 4-(5-Heptyl-1,3,4-Thiadiazol-2-yl)Benzene-1,3-Diol and 4-(5-Methyl-1,3,4-Thiadiazol-2-yl)Benzene-1,3-Diol Molecules Induced by $\mathrm{pH}$ Changes in Aqueous Solutions. J. Fluoresc. 2017, 27, 1201-1212. [CrossRef] [PubMed]

12. Matwijczuk, A.; Kluczyk, D.; Górecki, A.; Niewiadomy, A.; Gagoś, M. Solvent Effects on Molecular Aggregation in 4-(5-Heptyl-1,3,4-thiadiazol-2-yl)benzene-1,3-diol and 4-(5-Methyl-1,3,4-thiadiazol-2-yl)-benzene-1,3-diol. J. Phys. Chem. B 2016, 120, 7958-7969. [CrossRef] [PubMed]

13. Panda, D.; Singh, J.P.; Wilson, L. Suppression of microtubule dynamics by LY290181: A potential mechanism for its antiproliferative action. J. Biol. Chem. 1997, 272, 7681-7687. [CrossRef]

14. Wood, D.L.; Panda, D.; Wiernicki, T.R.; Wilson, L.; Jordan, M.A.; Singh, J.P. Inhibition of mitosis and microtubule function through direct tubulin binding by a novel antiproliferative naphthopyran ly290181. Mol. Pharmacol. 1997, 52, 437-444. [CrossRef] [PubMed]

15. Smith, C.W.; Bailey, J.M.; Billingham, M.E.J.; Chandrasekhar, S.; Dell, C.P.; Harvey, A.K.; Hicks, C.A.; Kingston, A.E.; Wishart, G.N. The anti-rheumatic potential of a series of 2,4-disubstituted-4H-naphtho[1,2-b]pyran-3-carbonitriles. Bioorg. Med. Chem. Lett. 1995, 5, 2783-2788. [CrossRef]

16. Kheirollahi, A.; Pordeli, M.; Safavi, M.; Mashkouri, S.; Naimi-Jamal, M.R.; Ardestani, S.K. Cytotoxic and apoptotic effects of synthetic benzochromene derivatives on human cancer cell lines. Naunyn-Schmiedeberg's Arch. Pharmacol. 2014, 387, 1199-1280. [CrossRef] [PubMed]

17. El-Agrody, A.M.; Abd El-Mawgoud, H.K.; Fouda, A.M.; Khattab, E.S.A.E.H. Synthesis, in-vitro cytotoxicity of $4 \mathrm{H}$-benzo[ $h]$ chromene derivatives and structure-activity relationships of 4-aryl group and 3-,7-positions. Chem. Pap. 2016, 70, 1279-1292. [CrossRef]

18. El-Agrody, A.M.; Fouda, A.M.; Khattab, E.S.A.E.H. Synthesis, antitumor activity of 2-amino-4H-benzo[ $h]$ chromene derivatives and structure-activity relationships of the 3- and 4-positions. Med. Chem. Res. 2013, 22, 6105-6120. [CrossRef]

19. El-Agrody, A.M.; Fouda, A.M.; Khattab, E.S.A.E.H. Halogenated 2-amino-4H-benzo[h]-chromene derivatives as antitumor agents and the relationship between lipophilicity and antitumor activity. Med. Chem. Res. 2017, 26, 691-700. [CrossRef]

20. El-Agrody, A.M.; Halawa, A.H.; Fouda, A.M.; Al-Dies, A.M. The antiproliferative activity of novel $4 H$-benzo $[h]$ chromenes, $7 \mathrm{H}$-benzo[ $h]$ chromeno[2,3- $d]$ pyrimidines and the structure-activity relationships of the 2-,3-positions and fused rings at the 2,3-positions. J. Saudi Chem. Soc. 2017, 21, 82-90. [CrossRef]

21. Halawa, A.H.; Fouda, A.M.; Al-Dies, A.M.; El-Agrody, A.M. Synthesis, biological evaluation and molecular docking studies of $4 H$-benzo[ $h]$ chromenes, $7 H$-benzo[ $h]$ chromeno[2,3-d]-Pyrimidinesas antitumor agents. Lett. Drug. Des. Discov. 2016, 13, 77-88. [CrossRef]

22. El-Agrody, A.M.; Fouda, A.M.; Al-Dies, A.M. Studies on the synthesis, in vitro antitumor activity of $4 H$-benzochromene,7H-benzo[ $h]$ chromeno[2,3- $d]$ pyrimidine derivatives and structure activity relationships of the 2-,3- and 2,3-positions. Med. Chem. Res. 2014, 23, 3187-3199. [CrossRef]

23. Plazzi, L.; Cavalli, A.; Belluti, F.; Bisi, A.; Gobbi, S.; Rizzo, S.; Bartolini, M.; Andrisano, V.; Recanatini, M.; Rampa, A. Extensive SAR and computational studies of 3-\{4-[(benzylmethyl-amino)methyl]phenyl\}-6,7-dimethoxy-2h-2-chromenone (AP2238) derivatives. J. Med. Chem. 2007, 50, 4250-4254. [CrossRef]

24. Rafinejad, A.; Fallah-Tafti, A.; Tiwari, R.; Shirazi, A.N.; Mandal, D.; Shafiee, A.; Parang, K.; Foroumadi, A.; Akbarzadeh, T. 4-Aryl-4H-naphthopyrans derivatives: One-pot synthesis, evaluation of Src kinase inhibitory and anti-proliferative activities. DARU J. Pharm. Sci. 2012, 20, 100-107. [CrossRef]

25. Ahmed, H.E.A.; El-Nassag, M.A.A.; Hassan, A.H.; Okasha, R.M.; Ihmaid, S.; Fouda, A.M.; Afifi, T.H.; Aljuhani, A.; El-Agrody, A.M. Introducing novel potent anticancer agents of $1 H$-benzo[f]chromene scaffolds, targeting c-Src kinase enzyme with MDA-MB-231 cell line anti-invasion effect. J. Enzyme Inhib. Med. Chem. 2018, 33, 1074-1088. [CrossRef] [PubMed] 
26. Okasha, R.M.; Alblewi, F.F.; Afifi, T.H.; Naqvi, A.; Fouda, A.M.; Al-Dies, A.M.; El-Agrody, A.M. Design of new benzo[ $h]$ chromene derivatives: Antitumor activities and structure-activity relationships of the 2,3-positions and fused rings at the 2,3-positions. Molecules 2017, 22, 479. [CrossRef] [PubMed]

27. Khafagy, M.M.; Abd El-Wahab, A.H.F.; Eid, F.A.; El-Agrody, A.M. Synthesis of halogen derivatives of benzo[ $[h]$ cheromene and benzo[a]anthracene with promising antimicrobial activities. IL Farmaco 2002, 57, 715-722. [CrossRef]

28. Mossman, T. Rapid colorimetric assay for cellular growth and survival: Application to proliferation and cytotoxicity assays. J. Immunol. Methods 1983, 65, 55-63. [CrossRef]

29. Rahman, A.U.; Choudhary, M.I.; Thomsen, W.J. Bioassay Technique for Drug Development; Harwood Academic: Amsterdam, The Netherlands, 2001; ISBN 0-203-34349-2.

30. Chan, K.T.; Meng, F.Y.; Li, Q.; Ho, C.Y.; Lam, T.S.; To, Y.; Lee, W.H.; Li, M.; Chu, K.H.; Toh, M. Cucurbitacin B induces apoptosis and $\mathrm{S}$ phase cell cycle arrest in BEL-7402 human hepatocellular carcinoma cells and is effective via oral administration. Cancer Lett. 2010, 294, 118-124. [CrossRef]

31. Shen, J.K.; Du, H.P.; Yang, M.; Wang, Y.G.; Jin, J. Casticin induces leukemic cell death through apoptosis and mitotic catastrophe. Ann. Hematol. 2009, 88, 743-752. [CrossRef]

32. Kohn, K.W.; Jackman, J.; O'Connor, P.M. Cell Cycle Control and Cancer Chemotherapy. J. Cell. Biochem. 1994, 54, 440-452. [CrossRef] [PubMed]

33. Marino, G.; Kroemer, G. Mechanisms of apoptotic phosphatidylserine exposure. Cell Res. 2013, 23, 1247-1248. [CrossRef] [PubMed]

34. Walsh, J.G.; Cullen, S.P.; Sheridan, C.; Luthi, A.U.; Gerner, C.; Martin, S.J. Executioner caspase-3 and caspase-7 are functionally distinct proteases. Proc. Natl. Acad. Sci. USA 2008, 105, 12815-12819. [CrossRef]

35. Kitazumi, I.; Tsukahara, M. Regulation of DNA fragmentation: The role of caspases and phosphorylation. FEBS J. 2011, 278, 427-441. [CrossRef]

36. Yang, H.; Ganguly, A.; Cabral, F. Inhibition of cell migration and cell division correlates with distinct effects of microtubule inhibiting drugs. J. Biol. Chem. 2010, 285, 32242-32250. [CrossRef] [PubMed]

37. Hashimoto, T.; Kikkawa, U.; Kamada, S. Contribution of caspase(s) to the cell cycle regulation at mitotic phase. PLoS ONE 2011, 6, e18449. [CrossRef] [PubMed]

38. Jang, J.Y.; Kang, Y.J.; Sung, B.; Kim, M.J.; Park, C.; Kang, D.; Moon, H.R.; Chung, H.Y.; Kim, N.D. MHY440, a Novel Topoisomerase I Inhibitor, Induces Cell Cycle Arrest and Apoptosis via a ROS-Dependent DNA Damage Signaling Pathway in AGS Human Gastric Cancer Cells. Molecules 2018, 24, 96. [CrossRef] [PubMed]

39. El-Agrody, A.M.; Fouda, A.M.; Al-Dies, A.M. Microwave assisted synthesis of 2-amino-6-methoxy-4H-benzo[h]chromene derivatives. Eur. J. Chem. 2014, 5, 133-137. [CrossRef]

40. Rosner, M.; Schipany, K.; Hengstschläger, M. Merging high-quality biochemical fractionation with a refined flow cytometry approach to monitor nucleocytoplasmic protein expression throughout the unperturbed mammalian cell cycle. Nat. Protoc. 2013, 8, 602-626. [CrossRef]

41. Boraschi, D.; Maurizi, G. Quantitation of DNA fragmentation with diphenylamine. In Apoptosis_A Laboratory Manual of Experimental Methods; Boraschi, D., Bossù, P., Cossarizza, A., Eds.; GCI Publications: L'Aquila, Italy, 1998; pp. 153-161.

Sample Availability: Samples of all the compounds are available from the authors. 